\title{
PENERAPAN PEMBELAJARAN TEMATIK INTEGRATIF BERBASIS KONTEKSTUAL UNTUK MENINGKATKAN KEAKTIFAN DAN HASIL BELAJAR SISWA KELAS 1 SD
}

\author{
Qurrotul Aini \\ Stefanus C. Relmasira \\ Universitas Kristen Satya Wacana \\ Jalan Diponegor 52-60 Salatiga \\ E-mail: Ainee1278@gmailcom
}

\begin{abstract}
This research aims to improve the activeness and learning outcomes of grade 1 students by applying contextual-based integrative thematic learning. This research is an action research consisting of two cycles. Data collection in the research using tests and non-tests. The results showed that there was an increase in activeness from good categories to be very good. Learning outcomes of BI, PPKn, and mathematics respectively $71 \%, 85 \%$, and $75 \%$ in cycle I increased to $78 \%, 89 \%$, and $85 \%$ in cycle II. Thus, the application of contextually based thematic integrated learning can improve the activeness and learning outcomes of grade 1 students of SD N Salatiga 03.
\end{abstract}

Keywords: thematic integrative, contextual, learning outcomes, activeness

\begin{abstract}
Abstrak: Penelitian bertujuan meningkatkan keaktifan dan hasil belajar siswa kelas 1 dengan menerapkan pembelajaran tematik integratif berbasis kontekstual. Penelitian penelitian tindakan kelas yang terdiri dari dua siklus dengan subyek siswa kelas I SDN Salatiga 03. Pengumpulan data menggunakan tes dan nontes. Hasil menunjukkan adanya peningkatan keaktifan dari kategori baik menjadi sangat baik. Ketuntasan hasil belajar siswa pada muatan pelajaran BI, PPKn, dan matematika berturut-turut $71 \%, 85 \%$, dan $75 \%$ pada siklus I meningkat menjadi $78 \%$, $89 \%$, dan $85 \%$ pada siklus II. Penerapan pembelajaran tematik integratif berbasis kontekstual dapat meningkatkan keaktifan dan hasil belajar siswa kelas 1 SD N Salatiga 03.
\end{abstract}

Kata kunci: tematik integratif, kontekstual, hasil belajar, keaktifan, SD.

Pendidikan Nasional berfungsi mengembangkan kemampuan dan membentuk watak serta peradaban bangsa yang bermartabat dalam rangka mencerdaskan kehidupan bangsa, bertujuan untuk mengembangkan potensi peserta didik agar menjadi manusia yang beriman dan bertakwa kepada Tuhan Yang Maha Esa, berakhlak mulia, sehat, berilmu, cakap, kreatif, mandiri, dan menjadi warga negara yang demokratis serta bertanggung jawab (Permendikbud Nomor 20 Tahun 2016). Untuk mewujudkan tujuan pendidikan nasional tersebut diperlukan profil kualifikasi kemampuan lulusan yang dituangkan dalam standar kompetensi lulusan.
Dalam penjelasan Pasal 35 Undang-Undang Nomor 20 Tahun 2003 disebutkan bahwa standar kompetensi lulusan merupakan kualifikasi kemampuan lulusan yang mencakup sikap, pengetahuan, dan keterampilan siswa yang harus dipenuhi atau dicapainya dari suatu satuan pendidikan pada jenjang pendidikan dasar dan menengah.

Undang-Undang Nomor 20 Tahun 2003 tentang Sistem Pendidikan Nasional menyebutkan bahwa kurikulum adalah seperangkat rencana dan pengaturan mengenai tujuan, isi, dan bahan pelajaran serta cara yang digunakan sebagai pedoman penyelenggaraan kegiatan pembelajaran untuk 
mencapai tujuan pendidikan tertentu. Berdasarkan pengertian tersebut, ada dua dimensi kurikulum, yang pertama adalah rencana dan pengaturan mengenai tujuan, isi, dan bahan pelajaran, sedangkan yang kedua adalah cara yang digunakan untuk kegiatan pembelajaran. Kurikulum 2013 berlaku mulai tahun ajaran 2013/2014 memuat kedua dimensi tersebut (Permendikbud Nomor 67 Tahun 2013).

Sesuai harapan Permendikbud nomor nomor 20 Tahun 2016, kompetensi yang harus dimiliki siswa adalah kompetensi sikap, kepribadian, dan keterampilan. Siswa diharapkan memiliki perilaku sikap beriman dan bertaqwa kepada Tuhan Yang Maha Esa, berkarakter, jujur, peduli, bertanggungjawab, sehat jasmani dan rohani sesuai dengan perkembangan anak di lingkungan keluarga, sekolah, dan masyarakat. Selain itu, siswa diharapkan mampu mengaitkan pengetahuan faktual, konseptual, prosedural dan metakognitif dalam konteks diri sendiri, keluarga, sekolah, masyarakat, dan lingkungan sekitar. Keterampilan yang diharapkan dimilliki siswa yaitu kreatif, produktif, kritis, mandiri, kolaboratif, dan komunikatif. Dengan demikian, siswa berkemampuan untuk menjadi manusia yang lebih produktif, kreatif, inovatif, dan afektif serta mampu berkontribusi pada kehidupan bermasyarakat.

Keberhasilan implementasi setiap kurikulum sangat bergantung bagaimana pelaksanaannya. Prinsip yang perlu diterapkan pada kurikulum 2013 adalah memotivasi siswa agar aktif mencari tahu, bukan diberi tahu. Hal ini sesuai dengan Permendikbud nomor 22 Tahun 2016 yang menyebutkan bahwa guru bukan satu-satunya sumber belajar karena belajar dapat melalui berbagai sumber. Pendekatan yang digunakan bukan lagi pendekatan tekstual namun pendekatan ilmiah. Pembelajaran yang digunakan tidak lagi bersifat parsial namun terpadu.

Tuntutan kurikulum 2013 berdasarkan uraian di atas salah satunya adalah penerapan pembelajaran yang mengaktifkan siswa yaitu pembelajaran tematik integratif. Terlebih lagi, kurikulum 2013 mewajibkan guru untuk merancang pembelajaran dengan model tematik integratif. Permendikbud No. 57 Tahun 2014 mengartikan pembelajaran tematik adalah suatu model pembelajaran yang menggunakan tema untuk mengaitkan berbagai mata pelajaran sehingga dapat memberikan pengalaman yang bermakna pada siswa. Suryosubroto (2009:133) menyatakan bahwa pembelajaran tematik adalah upaya pengintegrasian pengetahuan, keterampilan, sikap, serta pemikiran kreatif menggunakan tema.

Penerapan pembelajaran tematik di sekolah dasar menuntut adanya pembelajaran yang terintegrasi antar satu mata pelajaran dengan pelajaran lainnya, bahkan dengan kehidupan siswa sehari-hari. Meskipun buku guru dan buku siswa yang tersedia saat ini dapat dijadikan sumber belajar, namun perlu diupayakan adanya skenario pembelajaran yang terintegrasi untuk membantu siswa memahami berbagai ilmu pengetahuan yang berpangkal dari tema-tema yang melekat dalam kehidupan dan lingkungannya. Haryati (2016:201) berpendapat pembelajaran tematik integratif sangat cocok diajarkan pada siswa sekolah dasar, khususnya kelas rendah karena tahap pada tahap ini anak masih berfikir holistik, artinya anak masih memahami sesuatu sebagai satu kesatuan bukan terpisah-pisah.

Pembelajaran tematik dapat memberikan pengalaman bermakna pada siswa karena pembelajaran tematik menuntut siswa aktif dan menemukan sendiri pengetahuan yang mereka pelajari. Hal ini sesuai dengan Rusman (2012:254) yang menyatakan bahwa pembelajaran tematik integratif adalah suatu pembelajaran yang memungkinkan siswa aktif menggali dan menemukan konsep-konsep serta prinsip secara menyeluruh, bermakna, dan dapat dipercaya.

CiriCiripembelajarantematikmenurut (Trianto, 2011:163-164) yaitu: (1) berpusat pada anak, (2) memberikan pengalaman langsung, (3) pemisahan antar mata pelajaran tidak nampak, (4) menyajikan konsep dari beberapa mata pelajaran dalam satu proses belajar mengajar, (5) bersifat luwes, dan (6) hasil pembelajaran berkembang sesuai dengan minat dan kebutuhan siswa. Sedangkan menurut Suyanto (2013:180) pembelajaran tematik lebih menekankan pada keterlibatan siswa dalam proses belajar secara aktif dalam proses pembelajaran sehingga siswa dapat memperoleh pengalaman langsung dan terlatih untuk dapat menemukan berbagai pengetahuan yang dipelajarinya.

Penelitian tentang pembelajaran tematik pernah dilakukan oleh Endang (2015:13), Bernadi (2017:100), Sari (2015:82), dan Mawardi (2018:64). 
Keempat penelitian tersebut menyimpulkan bahwa pembelajaran tematik dapat meningkatkan hasil belajar siswa.

Endang (2015:13) menyimpulkan strategi pembelajaran tematik dapat meningkatkan aktivitas dan hasil belajar siswa. Hal tersebut dapat dilihat dengan adanya peningkatan aktivitas dan juga peningkatan nilai rata-rata siswa di tiap siklus. Penelitian yang serupa dilakukan pula oleh Bernadi (2017:100). Hasil penelitian yaitu pembelajaran pembelajaran tematik integratif dengan pendekatan open ended dapat meningkatkan kreativitas dan hasil belajar siswa. Selain itu, penelitian Mawardi (2018:64) menyimpulkan pembelajaran tematik integratif dapat memberikan pengalaman yang bermakna sehingga siswa dapat lebih mudah menyerap pembelajaran.

Pembelajaran tematik sangat penting diterapkan untuk mengembangkan sikap dan keterampilan peserta didik. Hal ini relevan dengan hasil penelitian yang dilakukan Sari (2015:82) yang membuktikan bahwa karakter disiplin dan tanggung jawab siswa kelas III SD dapat ditingkatkan melalui pelajaran buku pelajaran tematik integratif berbasis nilai. Sari (2015:74) menyebutkan bahwa model pembelajaran tematik integratif bertujuan mengembangkan potensi setiap peserta didik dalam memahami dan mendalami konsep materi secara utuh karena terintegrasi dalam tema. Pelaksanaan pembelajaran dengan model tematik integratif juga harus memperhatikan pengembangan nilai karakter dan pengembangan sikap peserta didik.

Pembelajaran kontekstual adalah sebuah sistem yang dapat merangsang otak untuk menyusun pola-pola yang mewujudkan makna (Johsnon. 2014:58). Lebih lanjut ia menyebutkan bahwa pembelajaran kontekstual adalah sistem pembelajaran yang menghasilkan makna dengan menghubungkan muatan akademis dengan konteks kehidupan siswa sehari-hari. Shoimin (2014:44) menyatakan bahwa dalam pembelajaran kontekstual, guru harus dapat menghadirkan dunia nyata ke dalam kelas dan mendorong siswa untuk membuat hubungan antara pengetahuan yang dimiliki ke dalam kehidupan nyata mereka sebagai bagian dari anggota keluarga dan masyarakat. Dengan menerapkan pembelajaran kontekstual, siswa akan lebih tertarik dengan pembelajaran. Hal tersebut sesuai pendapat Masdiana (2014:191) pelaksanaan pembelajaran yang kurang sesuai dengan karakteristik siswa mengakibatkan pola interaksi yang terjadi dalam proses pembelajaran kurang mengaktifkan dan kurang menarik bagi siswa.

Penelitian tentang kontekstual pernah dilakukan oleh Made Putra (2016:7) yang menyimpulkan bahwa bahwa penerapan pendekatan saintifik berbasis kontekstual dapat meningkatkan penguasaan kompetensi pengetahuan PKn pada tema cita-citaku siswa kelas IVa SD Negeri 1 Kerobokan Badung. Selain itu, hasil penelitian Setyowati (2017:57) menyimpulkan bahwa Contextual Teaching and Learning efektif digunakan pada pembelajaran IPA kelas IV SD. Hasil penelitian Muslimin (2015:98) menyatakan bahwa pembelajaran kontekstual dapat meninkatkan kreativitas siswa kelas $\mathrm{V}$ dalam memahami sifat cahaya.

Pembelajaran Kelas 1 SD Negeri Salatiga 03 sudah menerapkan kurikulum 2013. Berbagai upaya telah dilakukan untuk meningkatkan mutu guru diantaranya guru telah mengikuti pelatihan Kurikulum 2013, kelompok kerja guru (KKG), dan seminar. Pembelajaran di kelas I menerapkan pendidikan karakter dan literasi sesuai kurikulum 2013. Namun, jika dibandingan dengan SD lain, SD Salatiga 03 belum menduduki sekolah peringkat atas sesuai dengan visi misi. Berdasarkan observasi yang dilakukan oleh peneliti, jumlah siswa yang aktif dalam pembelajaran kelas 1 masih kurang. Jumlah siswa yang aktif dalam pembelajaran kelas 1 yaitu 12 dari 28 siswa atau hanya $42 \%$ siswa. Ada siswa yang sama sekali tidak mau menulis, dan empat siswa belum dapat membaca. Sedangkan hasil belajar siswa menunjukkan ketuntasan klasikal pada muatan pembelajaran PPKn sebesar $75 \%$ dengan nilai rata-rata 84 . Pada muatan Bahasa Indonesia ketuntasan klasikal siswa sebesar 71,4 \% dengan nilai rata-rata 82 . Pada muatan matematika ketuntasan klasikal sebesar $67 \%$ dengan nilai ratarata 81 .

Berdasarkan refleksi peneliti bersama guru, ditemukan penyebab dari kurang maksimalnya pembelajaran yaitu guru mengalami kesulitan dalam menerapkan Kurikulum 2013. Kesulitan tersebut disebabkan karena dalam pembelajaran guru hanya berpedoman pada buku guru dan buku siswa yang meterinya belum tentu sesuai dengan lingkungan siswa (kontekstual). Menurut guru, materi pada buku guru dan buku siswa terlalu banyak sehingga seringkali guru kekurangan waktu. Meskipun demikian, materi yang diajarkan sebenarnya masih 
dangkal sehingga siswa mudah lupa. Terkadang ada materi yang belum tersampaikan karena guru harus mematangkan pengetahuan konseptual kepada siswa. Hal ini akan berpengaruh terhadap keaktifan siswa dalam pembelajaran dan juga berpengaruh pada hasil belajar siswa.

Peneliti bersama tim kolaborator memutuskan permasalahan tersebut merupakan permasalahan yang perlu segera dipecahkan. Salah satu alternatif pemecahan masalah yang dilaksanakan oleh guru adalah penerapan pembelajaran tematik integratif berbasis kontekstual. Hal yang membedakan penelitian ini dengan penelitian sebelumnya adalah belum ada penelitian yang memperhatikan atau mengkombinasikan pembelajaran tematik integratif dengan pembelajaran kontekstual yang diyakini dapat meningkatkan keaktifan dan hasil belajar siswa.

Penelitian ini bertujuan meningkatkan keaktifan dan hasil belajar siswa kelas 1 SDN Salatiga 03. Manfaat penelitian ini yaitu dapat memberikan kontribusi bagi pengembangan model dan rancangan pembelajaran di sekolah. Penelitian juga bermanfaat untuk menambah wawasan, pengetahuan, dan keterampilan peneliti terkait tematik integratif berbasis kontekstual. Untuk guru, penelitian dapat memberikan wawasan pengetahuan dan pengalaman tentang penerapan pembelajaran tematik integratif berbasis kontekstual guna meningkatkan kreativitas guru dalam menyusun skenario pembelajaran.

\section{METODE}

Penelitian ini adalah penelitian tindakan kelas dengan tujuan meningkakan keaktifan dan hasil belajar siswa. Penelitian dilaksanakan sesuai dengan model Stringer. Menurut Yaumi (2014:45) dengan tiga tahapan yaitu melihat (look), berpikir (think), dan bertindak (act). Berikut adalah gambar model Stringer:

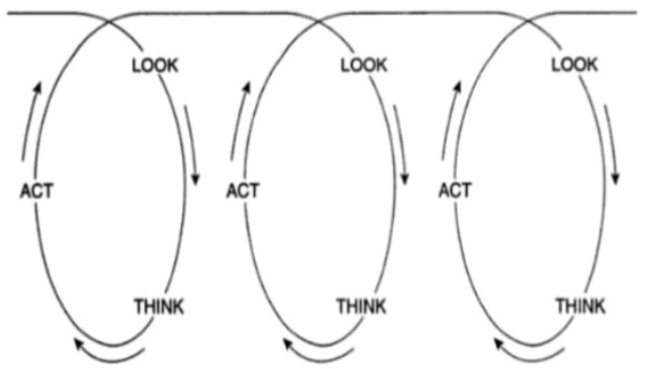

Gambar 1. Model Stringer
Setiap siklusnya dilakukan melihat atau observasi, berpikir pemecahan masalah, dan bertindak atau mengimplementasikan. Setelah melakukan tindakan dilakukan refleksi. Hasil refleksi siklus I dijadikan acuan untuk memperbaiki pembelajaran di siklus II. Apabila siklus II sudah memenuhi target ketuntasan klasikal, maka penelitian tindakan kelas dianggap berhasil.

Penelitian ini dilakukan di SDN Salatiga 03 Kecamatan Kota Salatiga. Subjek penelitian yaitu kelas 1 yang terdiri dari 16 siswa laki-laki dan 12 siswa perempuan. Variabel dalam penelitian ini yaitu pembelajaran tematik integratif berbasis kontekstual, keaktifan, dan hasil belajar siswa. Definisi operasional pertama yang digunakan dalam penelitian ini adalah pembelajaran tematik integratif berbasis kontekstual yaitu pembelajaran yang memuat beberapa muatan dalam suatu tema yang dihubungkan dengan situasi nyata siswa dalam kehidupan nyata. Kedua, keaktifan belajar yang merupakan aktivitas siswa selama pembelajaran. Ketiga, hasil belajar yaitu kemampuan siswa setelah mengikuti pembelajaran.

Data dikumpulkan menggunakan teknik tes dan nontes. Teknik tes digunakan untuk mengumpulkan data yang bersifat kuantitatif. Tes diberikan kepada siswa berupa pilihan ganda dan uraian setelah mengikuti pembelajaran dengan pembelajaran tematik integratif berbasis kontekstual. Sedangkan teknik nontes digunakan guru untuk mengamati keaktifan siswa dengan lembar observasi. Selain itu, dokumentasi dan catatan lapangan dilakukan untuk mengamati proses pembelajaran dengan menggunakan pembelajaran tematik integratif berbasis kontekstual.

Penelitian dikatakan berhasil apabila pembelajaran berjalan sesuai prosedur yang benar sehingga keaktifan dan hasil belajar siswa meningkat dengan ketuntasan klasikal minimal 75 \% dengan KKM 75. Teknik analisis data dalam penelitian ini menggunakan teknik deskriptif komparatif, yaitu membandingkan keaktifan dan hasil belajar siswa pada siklus I dan siklus II. Dengan perbandingan itu, maka akan diketahui peningkatan keaktifan dan hasil belajar siswa pada siklus I dan siklus II.

\section{HASIL}

Penelitian yang menerapkan pembelajaran tematik integratif berbasis kontekstual menunjukkan adanya peningkatan keaktifan dan hasil bela- 
jar siswa. Hasil observasi keaktifan siswa selama pembelajaran menunjukkan adanya peningkatan. Siklus I jumlah rata-rata perolehan skor keaktifan siswa 17 dengan kategori baik meningkat menjadi 20 dengan kategori sangat baik. Peningkatan data perolehan keaktifan siswa pada pembelajaran tematik integratif berbasis kontekstual dapat dilihat pada diagram berikut ini.

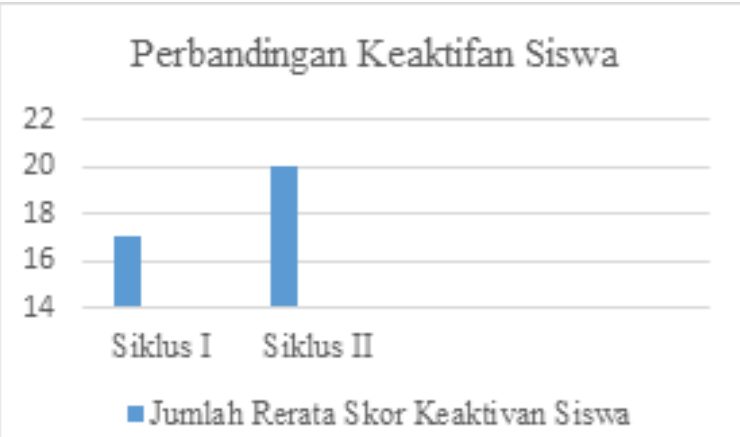

\section{Gambar 2: Diagram Perbandingan Keaktifan Siswa}

Selain data keaktifan, didapatkan data hasil belajar tiga muatan, yaitu Bahasa Indonesia, PPKn, dan Matematika pada pembelajaran tematik kelas 1 tema Benda, Hewan, dan Tumbuhan di Sekitarku subtema Merawat Hewan dan Tumbuhan di Sekitarku. Pada siklus I muatan Bahasa Indonesia terdapat 20 siswa dari 28 siswa $(71 \%)$ yang tuntas, dan 8 siswa dari 28 siswa (29\%) dengan kategori tidak tuntas. Sedangkan pada siklus II, terdapat 22 siswa dari 28 siswa $(78 \%)$ dengan kategori tuntas dan 6 siswa dari 28 siswa (22\%) dengan kategori tidak tuntas. Rata-rata nilai secara klasikal pada siklus I muatan Bahasa Indonesia adalah 79,5 dan pada siklus II adalah 79,3.

Tabel 1. Hasil Belajar Muatan Bahasa Indonesia Siklus I dan II

\begin{tabular}{|c|c|c|c|c|}
\hline \multirow{2}{*}{ Kategori } & \multicolumn{2}{|c|}{ Siklus I } & \multicolumn{2}{c|}{ Siklus II } \\
\cline { 2 - 5 } & F & \% & F & \% \\
\hline Tuntas & 20 & $71 \%$ & 22 & $78 \%$ \\
\hline $\begin{array}{c}\text { Tidak } \\
\text { tuntas }\end{array}$ & 8 & $29 \%$ & 6 & $15 \%$ \\
\hline Total & 28 & $100 \%$ & 28 & $100 \%$ \\
\hline Rata-rata & 79,5 & & 79,3 & \\
\hline
\end{tabular}

Berikutnya adalah hasil belajar PPKn. Pada siklus I dan siklus II terdapat 25 siswa dari 28 siswa (89\%) dengan kategori tuntas, dan 5 siswa dari 28 siswa (11\%) dengan kategori tidak tuntas. Rata-rata nilai secara klasikal siklus I muatan PPKn adalah 87,9 sedangkan pada siklus II adalah 88,2.

\section{Tabel 2. Hasil belajar PPKn siklus I dan siklus II}

\begin{tabular}{|c|c|c|c|c|}
\hline \multirow{2}{*}{ Kategori } & \multicolumn{2}{|c|}{ Siklus I } & \multicolumn{2}{c|}{ Siklus II } \\
\cline { 2 - 5 } & F & \% & F & \% \\
\hline Tuntas & 25 & $89 \%$ & 25 & $89 \%$ \\
\hline & & & & \\
\hline $\begin{array}{c}\text { Tidak } \\
\text { tuntas }\end{array}$ & 5 & $11 \%$ & 5 & $11 \%$ \\
\hline Total & 28 & $100 \%$ & 28 & $100 \%$ \\
\hline Rata-rata & 87,9 & & 88,2 & \\
\hline
\end{tabular}

Selanjutnya adalah perolehan hasil belajar muatan matematika pada siklus I dan siklus II. Pada siklus I terdapat 21 siswa dari 28 siswa (75\%) dengan kategori tuntas, dan 7 siswa dari 28 siswa $(25 \%)$ dengan kategori tidak tuntas.

Pada siklus II, hasil belajar matematika mengalami peningkatan. Terdapat 24 siswa dari 28 siswa (85\%) dengan kategori tuntas dan 4 siswa lainnya (15\%) tidak tuntas. Hasil belajar Matematika dari siklus I rata-rata klasikalnya 80,4 menjadi 84,4 pada siklus II, sehingga dapat disimpulkan hasil belajar matematika mengalami peningkatan.

\section{Tabel 3. Hasil belajar Matematika} siklus I dan siklus II

\begin{tabular}{|c|c|c|c|c|}
\hline \multirow{2}{*}{ Kategori } & \multicolumn{2}{|c|}{ Siklus I } & \multicolumn{2}{c|}{ Siklus II } \\
\cline { 2 - 5 } & F & \% & F & \% \\
\hline Tuntas & 21 & $75 \%$ & 24 & $85 \%$ \\
\hline $\begin{array}{c}\text { Tidak } \\
\text { tuntas }\end{array}$ & 7 & $25 \%$ & 4 & $15 \%$ \\
\hline Total & 28 & $100 \%$ & 28 & $100 \%$ \\
\hline Rata-rata & 80,4 & & 84,4 & \\
\hline
\end{tabular}

Peningkatan ketuntasan klasikal tiap muatan pelajaran pada siklus I dan siklus II dapat dilihat pada diagram di bawah ini.

Berdasarkan diagram di atas, hasil belajar muatan Bahasa Indonesia yang diperoleh pada siklus I belum mencapai target ketuntasan klasikal. Sedangkan hasil PPKn sudah melampaui target ketuntasan, dan untuk muatan matematika mencapai target ketuntasan. Sedangkan pada siklus II, terjadi peningkatan hasil belajar yaitu dari ketuntasan klasikal sebesar $71 \%$ menjadi $78 \%$ untuk muatan 
pelajaran Bahasa Indonesia, sedangkan pada muatan PPKn ketuntasan klasikal sama-sama sebesar $89 \%$, dan pada muatan matematika ketuntasan klasikal dari 75\% menjadi 85\%. Dengan demikian, hasil belajar siklus II sudah mencapai indikator keberhasilan.

\section{PEMBAHASAN}

Pelaksanaan penelitian dilakukan oleh peneliti sebanyak dalam dua siklus. Siklus pertama dilaksanakan pada hari Jumat 23 Maret 2018, sedangkan siklus kedua dilaksanakan pada Jumat 6 April 2018. Siklus kedua dilakukan menurut hasil perbaikan dari refleksi pada siklus pertama.

Penelitian dilatarbelakangi oleh permasalahan yang dilakukan pada saat observasi. Peneliti dan tim kolaborator melakukan refleksi guna menentukan pemecahan masalah pembelajaran kelas 1. Pada tahap ini, peneliti menyusun instrumen berupa RPP, bahan ajar, media, dan perangkat pembelajaran lainnya yaitu perangkat pembelajaran tematik integratif berbasis kontekstual. Peneliti memilih pembelajaran tematik berbasis kontekstual agar pembelajaran lebih nyata dan dekat dengan lingkungan peserta didik sehingga anak lebih aktif dan hasil belajar menjadi meningkat. Hal tersebut sesuai dengan pendapat Perwitasari (2017) yang menyatakan bahwa untuk meningkatkan hasil belajar siswa diperlukan penguasaaan konsep melalui kegiatan pembelajaran yang memadukan berbagai bidang studi ke dalam satu tema yang terkait dalam kehidupan sehari-hari.

Penelitimengembangkanmateri agarlebih dekat dengan lingkungan peserta didik (kontekstual). Hal ini sesuai dengan pendapat Muga (2018:23) yang menyebutkan bahwa pembelajaran kontekstual dapat membantu guru mengaitkan materi yang diajarkannya dengan dunia nyata siswa tersebut sehingga dapat mendorong siswa untuk membuat hubungan antara pengetahuan yang dimiliki dengan penerapannya dalam keseharian mereka.

Peneliti merancang perangkat pembelajaran dengan cara menganalisis jejaring tema yang ada di buku guru. Kemudian, membuat RPP, bahan ajar, media sesuai jejaring tema. Hal yang sama telah dilakukan pada penelitian Marzuki (2018:165) pembelajaran yang dilakukan oleh guru dengan tematik model webbed berbasis lingkungan agar anak mampu berpikir tingkat tinggi sebagai berikut: (1) menghubungkan beberapa bidang studi yang ber- sangkutan kedalam sebuah tema, (2) menghubungkan pengetahuan dan keterampilan anak kedalam dunia nyata di lingkungan sekeliling mereka, (3) mengembangkan pengetahuan, keterampilan, dan kecakapan hidup anak secara simultan dan terus menerus, dan (4) menggabungkan dan mengembangkan suatu konsep dari berbagai bidang studi sehingga anak memahami dengan utuh.

Peneliti mengintegrasikan muatan pelajaran PPKn, Bahasa Indonesia, dan Matematika menjadi satu kesatuan. Pada siklus I, tema yang digunakan adalah Tema Benda, Hewan, Tumbuhan di Sekitarku, Subtema Merawat Hewan di Sekitarku, pembelajaran diberi nama Kelinciku. Yang dilakukan oleh peneliti sepemikiran dengan pendapat Wahyuni (2016:131) yang menyatakan bahwa guru yang kreatif harus dapat merancang suatu pembelajaran yang disajikan dalam suatu tema pokok untuk beberapa mata pelajaran sehingga pergantian antar muatan pelajaran tidak terlihat dan menjadi pembelajaran yang utuh dan menyeluruh.

Tahapan yang dilakukan peneliti dalam penelitian adalah mengobservasi atau melihat (look). Observasi dilaksanakan dengan mengamati proses belajar mengajar tematik di kelas 1 . Selain itu, peneliti melakukan wawancara dengan guru kelas. Berdasarkan observasi yang telah dilakukan, peneliti bersama tim kolaborator merencakan suatu tindakan pada pembelajaran tematik (think). Peneliti bersama tim kolaborator menganalisis jejaring tema yaitu menentukan KD dan indikator yang akan dicapai dalam tindakan.

Pelaksanaan tindakan (act) dilaksanakan selama dua siklus. Pada siklus I, muatan pelajaran yang diajarkan adalah Bahasa Indonesia, PPKn, dan matematika. Ketiga muatan pelajaran tersebut diintegrasikan menjadi satu kesatuan sehingga menjadi terpadu. Tema yang digunakan sebagai pemersatu adalah Benda, Hewan dan Tumbuhan di Sekitarku. Subtema nya yaitu Merawat Hewan di Sekitarku untuk siklus I dan Merawat Tanaman di Sekitarku untuk siklus II. Masing-masing siklus terdiri dari satu pembelajaran yang terpadu. Pembelajaran pada siklus I dijadikan sub-subtema dengan nama "Kelinciku" dan pada siklus II diberi nama "Pohon Jambu" agar pembelajaran lebih dekat dengan kehidupan siswa.

Hasil pengamatan yang didapat pada pelaksanaan siklus I diantaranya siswa aktif membaca teks tentang aturan memelihara kelinci di rumah. Siswa 
kemudian mengamati tayangan video cara merawat kelinci. Siswa aktif menjawab pertanyaan guru tentang tayangan video. Siswa diberi kesempatan untuk bertanya mengenai cara merawat kelinci namun keaktifan siswa dalam hal bertanya masih sangat rendah. Hal ini terbukti dengan tidak ada siswa yang bertanya kepada guru.

Selanjutnya siswa membandingkan gambargambar cara merawat kelinci yang benar dan cara merawat kelinci yang salah. Pada muatan Bahasa Indonesia, siswa secara berkelompok menyusun kosa kata menjadi kalimat pemberitahuan tentang kelinci yang dilengkapi dengan gambar. Papan pemberitahuan yang telah dikerjakan siswa tersebut dibacakan di depan kelas oleh setiap kelompok kemudian ditempelkan di papan tulis. Selanjutnya siswa memperhatikan cara menghitung jumlah gambar kelinci putih, kelinci hitam, dan kelinci abuabu. Siswa dengan bimbingan guru membandingkan jumlah gambar kelinci kemudian mengurutkan dari yang terkecil ke yang terbesar. Siswa berlatih mengurutkan bilangan secara berpasangan. Dalam hal ini beberapa siswa masih kurang teliti dalam menghitung jumlah bilangan.

Hasil belajar siklus I belum mencapai indikator keberhasilan yang ditetapkan. Hal ini terjadi karena beberapa kendala seperti (1) siswa kurang memperhatikan materi yang diberikan guru, (2) keterlibatan siswa dalam diskusi kelompok belum maksimal, dan (3) siswa tidak berani bertanya. Peneliti bersama tim kolaborator melakukan refleksi atas tindakan yang dilakukan pada siklus I. Hasil refleksi dijadikan bahan perbaikan agar kendala yang terjadi pada siklus I dapat teratasi sehingga pelaksanaan siklus II dapat berjalan lebih baik.

Pada siklus II tema yang digunakan masih sama yaitu Benda, Hewan, dan Tumbuhan di Sekitarku. Namun subtema pada siklus II ini yaitu Merawat Tanaman di Sekitarku. Dibandingkan dengan siklus I, materi ajar pada siklus II ini lebih padu dan terintegrasi. Perpindahan antar muatan pelajaran tidak begitu terlihat. Peneliti bersama tim kolaborator membuat sebuah cerita tentang "Pohon Jambu" yang memadukan beberapa KD dari tiga muatan pelajaran. Pembelajaran ini lah yang kemudian diberi nama "Pohon Jambu" agar lebih kontekstual sehingga siswa lebih memperhatikan guru. Siswa dimotivasi untuk lebih aktif dalam diskusi kelompok. Pemberian reward juga diberikan kepada siswa yang aktif bertanya.
Deskripsi siklus II diawali dengan tayangan video lagu "Papaya" dan menyanyikan lagu bersama. Kemudian siswa mengamati tayangan video tentang mengenal pohon jambu dan cara merawatnya. Siswa melakukan tanya jawab tentang video tersebut. Setelah tanya jawab, siswa aktif membaca teks yaitu cerita tentang cara merawat pohon jambu yang ditampilkan melalui microsoft power point. Teks tersebut berisi tentang pembagian tugas merawat tanaman di rumah (muatan PPKn). Di dalam teks terdapat pula suatu percakapan keluarga Edo yang mengandung ungkapan pujian. Siswa diminta menemukan ungkapan pujian dalam teks tersebut. Siswa memperhatikan beberapa gambar yang berkaitan dengan aturan merawat tanaman, kemudian menganalisis apakah gambar tersebut termasuk aturan merawat tanaman yang benar atau aturan merawat tanaman yang salah. Selanjutnya siswa secara berpasangan menyusun kosa kata menjadi kalimat pujian lalu dibalas dengan ucapan terima kasih secara lisan dan tulisan. Siswa menulis kalimat pujian tersebut pada kertas yang disediakan guru kemudian menempelnya di papan. Kegiatan ini membuat siswa lebih aktif menulis dan mempraktekkannya di depan kelas. Setelah membuat ungkapan pujian, siswa melanjutkan membaca cerita tentang Keluarga Edo yang sedang memetik buah jambu. Siswa menghitung buah jambu yang dipetik keluarga Edo sebelum mengerjakan LKPD menghitung penjumlahan benda konkret.

Keaktifan siswa pada siklus II meningkat jika dibandingkan dengan keaktifan siswa di siklus I. Hal tersebut dibuktikan dengan semakin banyaknya siswa yang terlibat aktif, mengikuti setiap kegiatan pembelajaran secara antusias yang meliputi; 1) merespon apersepsi; 2) bertanya dan menjawab pertanyaan; 3) bekerja sama dalam kelompok; 4) menyusun kota kata menjadi kalimat ; 5) menghitung dan mengurutkan bilangan; dan 6) mengkomunikasikan hasil diskusi di depan kelas. Jika sebelumnya di siklus I keterampilan bertanya siswa masih sangat rendah, di siklus II ini siswa berani bertanya tentang perbedaan merawat pohon jambu dengan merawat pohon lain. Selain itu, siswa juga bertanya tentang istilah dalam merawat tanaman yang belum pernah mereka dengar. Dengan demikiam, siswa sudah melakukan suatu usaha yang bertujuan meningkatkan hasil belajarnya. Hal ini senada dengan pendapat Kristin (2017) mengenai 
keaktifan yaitu keaktifan fisik dan mental dalam proses guna menunjang keberhasilan hasil belajar.

Peningkatan keaktifan siswa pada siklus II dipengaruhi oleh sumber belajar. Dengan kata lain, sumber belajar yang digunakan guru sangat berpengaruh pada aktivitas siswa. Hal serupa dinayatakan oleh Lestariningsih (2017:88) yang menyebutkan sumber belajar tematik integratif sangat diperlukan agar penerapan pembelajaran terlaksana dengan baik. Pemerintah sebagai pencetus Kurikulum 2013 telah menyediakan sumber belajar berupa buku guru dan buku siswa untuk mendukung pelaksanaan kurikulum. Namun, buku guru dan buku siswa yang disediakan oleh pemerintah ini cakupan materinya masih bersifat umum karena diperuntukkan bagi siswa di seluruh Indonesia. Permasalahan ini menuntut guru agar mampu mengembangkan materi atau bahan ajar sesuai dengan kebutuhan siswa sehingga lebih kontekstual.

\section{SIMPULAN DAN SARAN}

\section{Simpulan}

Berdasarkan hasil penelitian dapat disimpulkan bahwa penerapan pembelajaran tematik integratif berbasis kontekstual dapat meningkatkan keaktifan dan hasil belajar siswa kelas 1 SD Negeri Salatiga 03 tahun pelajaran 2017/2018. Pelaksanaan pembelajaran sudah terpadu sesuai tuntutan Kurikulum 2013 dan ciri-ciri tematik integratif. Sebelum pelaksanan pembelajaran dilakukan persiapan membuat perangkat pembelajaran termasuk RPP. Langkah pertama dalam membuat RPP adalah dengan mengintegrasikan KD beberapa muatan pelajaran agar berkaitan kemudian membuat indikator pembelajaran. Yang digunakan sebagai pengait antar muatan pelajaran adalah tentang kelinci pada siklus I dan tentang pohon jambu di siklus II sehingga antar muatan pelajaran tidak terpisahpisah. Selain bahan ajar yang sudah terintegrasi, penelitian menerapkan langkah pembelajaran dan media yang mengaktifkan siswa.

\section{Saran}

Saran ditujukan kepada guru sekolah dasar bahwa dalam merencanakan pelaksanaan pembelajaran hendaknya guru mempersiapkan perangkat secara matang seperti pembuatan RPP.
Dalam pembuatan indikator hendaknya guru menentukan suatu kata kunci yang dapat dijadikan sebagai pengait antar muatan pelajaran agar terpadu. Langkah-langkah pembelajaran hendaknya disesuaikan dengan tuntutan kurikulum 2013 yang bersifat kontekstual dan mengaktifkan siswa.

\section{DAFTAR RUJUKAN}

Bernadi, Resna M. A. 2017. Peningkatan Kreativitas Siswa Kelas IV SD Melalui Pembelajaran Tematik Integratif dengan Pendekatan OpenEnded. Jurnal Prima Edukasia 5 (1), 91-101.

Endang, S. E. S. (2015). Penerapan Strategi Pembelajaran Tematik Untuk Meningkatkan Kreativitas Dan Hasil Belajar Siswa. Jurnal Paradigma Institut, 1(1).

Haryati, S. (2016). Pengaruh Ssp Tematik Integratif Terhadap Peningkatkan Karakter Kejujuran Dan Kepedulian Siswa Kelas Ii SD. Jurnal Prima Edukasi, 4(2), 198-208.

Johnson, B. Elaine. 2014. Contextual Teaching and Learning: Menjadikan Kegiatan Belajar Mengajar Mengasyikkan dan Bermakna. Terjemahan Ibnu Setiawan. Bandung: Kaifa.

Kemendikbud. 2013. Permendikbud No 67 tentang kerangka Dasar dan Struktur Kurikulum Sekolah dasar/ Madrasah Ibtidaiyah. Jakarta: Kementerian Pendidikan dan Kebudayaan

Kemendikbud. 2014. Permendikbud No 57 Tahun 2014 tentang Kurikulum 2013 Sekolah Dasar / MI. Jakarta: Kemendibud.

Kemendikbud. 2016. Permendikbud No 20 tentang Standar Kompetensi Lulusan Pendidikan Dasar dan Menengah. Jakarta: Kementerian Pendidikan dan Kebudayaan

Kemendikbud. 2016. Permendikbud No 22 tentang Standar Standar Pendidikan Dasar dan Menengah. Jakarta: Kementerian Pendidikan dan Kebudayaan.

Kristin, F. (2017). Keberhasilan Belajar Mahasiswa Ditinjau Dari Keaktifan Dalam Perkuliahan Dengan Menggunakan Pembelajaran Active Learning. Jurnal Pendidikan Dasar Perkhasa, 3(2), 405-413.

Lestariningsih, N., \& Suardiman, S. P. 2017. Pengembangan Bahan Ajar Tematik-Integratif Berbasis Kearifan Lokal Untuk Meningkatkan Karakter Peduli Dan Tanggung Jawab. Jurnal Pendidikan Karakter, 7(1) 
Made Putra, M. P., Negara, I. G. A. O., \& Ke, S. P. M. (2016). Penerapan Saintifik Berbasis Kontekstual Meningkatkan Kompetensi Pengetahuan Pkn Kelas Iv Sd Negeri 1 Kerobokan Badung. MIMBAR PGSD Undiksha, 4(1).

Marzuki, M. (2018). Pembelajaran Tematik Model Webbed Berbasis Saintifik Terhadap Kemampuan Berpikir Tingkat Tinggi di SD. Sekolah Dasar: Kajian Teori dan Praktik Pendidikan, 26(2), 159-168.

Masdiana, M., Budiarsa, I. M., \& Lamba, H. A. 2014. Penerapan Pembelajaran Tematik untuk Meningkatkan Hasil Belajar IPA Materi Pada Lingkungan Siswa Kelas I SDN 018 Letawa Kecamatan Sarjo Kabupaten Mamuju Utara. Jurnal Kreatif Tadulako Online, 3(2).

Mawardi, M. (2018). Penerapan Desain Pembelajaran Tematik Integratif Alternatif Berbasis Kearifan Lokal untuk Meningkatkan Hasil dan Kebermaknaan Belajar. Mimbar Sekolah Dasar, 5(2), 63-74.

Muga, W., Oje, M. S., \& Laksana, D. N. L. (2018). Hasil Belajar Kognitif Siswa Sd Dalam Pembelajaran Kontekstual Media Mazi (Studi Pada Siswa Sd Kelas Tinggi). Journal of Education Technology, 2(1), 20-25.

Muslimin, M., Irfan, M., \& Sahabuddin, E. S. (2015). Meningkatkan Kreativitas Siswa Memahami Konsep Sifat Cahaya Melalui Pembelajaran Kontekstual Di SD. Indonesian Journal of Educational Studies, 18(2).
Perwitasari, S., \& Wahjoedi, W. (2017). Bahan Ajar Tematik Berbasis Kontekstual Untuk Siswa Sekolah Dasar. In Prosiding Seminar Nasional Mahasiswa Kerjasama Direktorat Jenderal Guru dan Tenaga Kependidikan Kemendikbud 2016.

Setyowati, D. W. N. (2017). Keefektifan Pendekatan Ctl Terhadap Hasil Belajar Ipa Materi Sumber Daya Alam. Phenomenon: Jurnal Pendidikan MIPA, 7(1), 50-57.

Shoimin, Aris. 2014. 68 Model Pembelajaran Inovatif dalam Kurikulum 2013. Jogjakarta: Ar-Ruzz Media

Rusman. (2012). Model-model Pembelajaran. Depok: Rajagrafindo

Sari, I. P., \& Syamsi, K. (2015). Pengembangan buku pelajaran tematik-integratif berbasis nilai karakter disiplin dan tanggung jawab di sekolah dasar. Jurnal Prima Edukasia, 3(1), 73-83.

Suryosubroto. (2009). Proses Belajar Mengajar di Sekolah. Jakarta: PT.Rineka Cipta.

Trianto. 2011. Model Pembelajaran Tematik Terpadu. Jakarta: Bumi Aksara.

Wahyuni, H. T., Setyosari, P., \& Kuswandi, D. (2016). Implementasi Pembelajaran Tematik Kelas 1 Sd. Edcomtech Jurnal Kajian Teknologi Pendidikan, 1(2).

Yaumi, M \& Damopodil, M. 2014. Action Research: Teori, Model, dan Aplikasi. Jakarta: Penerbit Kencana. 